\title{
STRUKTUR KERAK BUMI DI JAWA TIMUR BERDASARKAN ANALISIS FUNGSI PENERIMA TELESEISMIK
}

\section{CRUSTAL STRUCTURE IN EAST JA VA BASED ON RECEIVER FUNCTION ANALYSIS}

\author{
Puji Ariyanto $^{1^{*}}$, Maryam Sidiqa ${ }^{1}$, Bayu Pranata $^{2}$, Bambang S. Prayitno ${ }^{2}$ \\ ${ }^{1}$ Sekolah Tinggi Meteorologi Klimatologi dan Geofisika, Tangerang Selatan \\ ${ }^{2}$ Pusat Gempa Bumi dan Tsunami, Badan Meteorologi Klimatologi dan Geofisika, Jakarta
}

Received: 2021, October $26^{\text {th }}$

Accepted: 2021, November $15^{\text {th }}$

Keywords:

Crustal structure;

East Java;

Moho;

$\mathrm{P}$ and $\mathrm{S}$ wave velocity;

Receiver function.

\section{Corespondent Email:}

puji.ariyanto@stmkg.ac.id

\section{How to cite this article:}

Ariyanto, P., Maryam S., Bayu P., dan Bambang S.P. (2021).

Struktur Kerak Bumi di Jawa

Timur Berdasarkan Analisis

Fungsi Penerima Teleseismik.
Abstrak. Jawa Timur merupakan salah satu wilayah Indonesia yang memiliki kondisi tektonik yang aktif. Penelitian ini bertujuan untuk mengetahui struktur kerak bumi di wilayah Jawa Timur meliputi: ketebalan kerak bumi, model kecepatan gelombang $P$ dan $S$. Penelitian ini menggunakan analisis fungsi penerima dari gempa teleseismik dengan jarak episenter $30-90^{\circ}$ dan magnitudo $\geq 6$ yang terekam pada 6 stasiun seismik broadband milik Badan Meteorologi Klimatologi dan Geofisika (BMKG) yang berada pada 3 zona geologi utama di Jawa Timur, yaitu: stasiun TBJI dan GRJI di Zona Rembang, Stasiun LUJI dan ABJI di Zona Kendeng, serta stasiun PWJI dan GEJI di Zona Pegunungan Selatan. Hasil penelitian menunjukkan ketebalan kerak pada Zona Rembang sekitar 25-28 km pada stasiun TBJI dan 23-27 km pada stasiun GRJI, dengan nilai kecepatan gelombang seismik yang relatif sedang. Pada Zona Cekungan Kendeng di bawah stasiun LUJI dan ABJI, ketebalan kerak lebih tipis yaitu 18$20 \mathrm{~km}$, dengan model kecepatan gelombang seismik relatif rendah. Sedangkan pada Zona Pegunungan Selatan mempunyai ketebalan kerak lebih tebal yaitu 34-37 km di bawah stasiun PWJI dan 37-40 km di bawah stasiun GEJI, dengan kecepatan gelombang seismik lebih tinggi. Adanya penebalan dan penipisan kerak diperkirakan karena adanya efek isostasi.

Abstract. East Java is one of the regions in Indonesia that has active tectonics. This study aims to determine crustal structure in the East Java Region, including crustal thickness, the $P$ and $S$ wave velocity model. This study used receiver function analysis from teleseismic data with an epicenter distance of $30^{\circ}-90^{\circ}$ and magnitude $\geq 6$ recorded by 6 broadband seismic stations owned by the Agency of Meteorology, Climatology, and Geophysics (BMKG). The stations are located in 
Jurnal Geofisika Eksplorasi, 07(03), 202-225.

(c) 2021 JGE (Jurnal Geofisika Eksplorasi). This article is an openaccess article distributed under the terms and conditions of the Creative Commons Attribution (CC BY NC) three main geological zones in East Java, namely: TBJI and GRJI stations in Rembang Zone, LUJI and ABJI stations in the Kendeng Zone, and PWJI and GEJI stations in the Southern Mountains Zone. The results showed that the crustal thickness in the Rembang Zone was around 25-28 km at the TBJI station and $23-27 \mathrm{~km}$ at the GRJI station, with relatively moderate seismic wave velocity values. In the Kendeng Basin Zone below the LUJI and ABJI stations, the crustal thickness is 18-20 km thinner, with a relatively low seismic wave velocity model. Meanwhile, the Southern Mountain Zone has a thicker crust, 34-37 km below the PWJI station and 37-40 km below the GEJI station, with higher seismic wave velocities. The thickening and thinning of the crust are thought to be due to an isostatic effect.

\section{PENDAHULUAN}

Jawa Timur merupakan salah satu daerah di Indonesia yang memiliki kondisi tektonik yang aktif. Kondisi tersebut disebabkan oleh beberapa faktor, yang pertama adalah zona subduksi di Selatan Jawa Timur yang merupakan pertemuan antara Lempeng Samudra Australia yang menunjam ke bawah Lempeng Benua Eurasia dengan kecepatan pergerakan $4 \mathrm{~cm} /$ tahun (Katili, 1975; PUSGEN, 2017). Subduksi ini dikenal dengan nama Megathrust Jawa segmen Jateng-Jatim (JJ) yang memanjang hingga $440 \mathrm{~km}$ dan dapat mengakibatkan gempa hingga magnitudo 8,9. Faktor selanjutnya yaitu sesar-sesar yang terdapat di Jawa Timur, diantaranya adalah Sesar Baribis-Kendeng segmen Cepu, Waru, dan Surabaya; Sesar Pasuruan; Sesar Probolinggo; Sesar Baluran; Sesar Belumbang; dan Sesar Wonorejo (PUSGEN, 2017). Selain dipengaruhi oleh aktivitas tektonik, seismisitas di Jawa Timur juga dipengaruhi oleh adanya gunung api aktif yang tersebar di provinsi tersebut yaitu Gunung Kelud, Gunung Arjuno Welirang, Gunung Bromo, Gunung Semeru, Gunung Lamongan, Gunung Raung, dan Gunung Ijen (PVMBG, 2021).

Daerah Jawa Timur memiliki tingkat seismisitas yang tinggi ditandai dengan 3000 kejadian gempa selama 10 tahun terakhir dan 170 gempanya merupakan gempa dengan magnitudo $\geq 5$ (Gambar 1). Menurut Katalog
Gempa Bumi Signifikan dan Merusak BMKG 1821-2018 terdapat sekitar 27 kejadian gempa merusak. Gempa-gempa tersebut di antaranya yaitu Gempa Malang (1958), Gempa Tulungagung (1960), Gempa Wlingi (1962), Gempa Ponorogo (1963), Gempa Malang (1967), Gempa Malang (1972), Gempa Blitar (1998), Gempa Situbondo (2007), Gempa Malang (2013), Gempa Madiun (2015), Gempa Kabupaten Malang (2016), Gempa Situbondo (2018), dan Gempa Sumenep (2018). Selain terdapat gempa merusak, terdapat juga gempa yang menyebabkan tsunami berdasarkan Katalog Tsunami Indonesia Tahun 416-2018 yaitu gempa Banyuwangi 2 Juni 1994 yang mengakibatkan tsunami hingga 13,9 m (BMKG, 2019).

Berdasarkan kondisi tersebut, maka penelitian mengenai struktur kerak bumi sangat penting untuk memahami geodinamika lempeng di bawah permukaan serta akibatnya ke permukaan. Metode fungsi penerima merupakan metode yang umum digunakan untuk menggambarkan struktur kerak bumi menggunakan gempa teleseismik yang terekam pada seismograf 3 komponen. Metode ini memanfaatkan gelombang $P$ yang terkonversi menjadi gelombang $P$ s pada batas lapisan kerak bawah dan mantel atas yang mempunyai kontras impedansi, atau dikenal sebagai lapisan diskontinuitas Mohorovicic atau 'Moho'. Lapisan Moho merupakan bidang 
batas antara kerak bawah dengan komposisi batuan mafik dan mantel atas dengan komposisi batuan ultramafik ditandai dengan peningkatan kecepatan gelombang seismik yang signifikan (Jarchow \& Thompson, 1989). Informasi mengenai struktur kerak diperoleh dengan melakukan dekonvolusi seismogram komponen horizontal terhadap komponen vertikal. Proses dekonvolusi ini dilakukan untuk menghilangkan informasi mengenai sumber dan respon instrument (Lay \& Wallace, 1995).

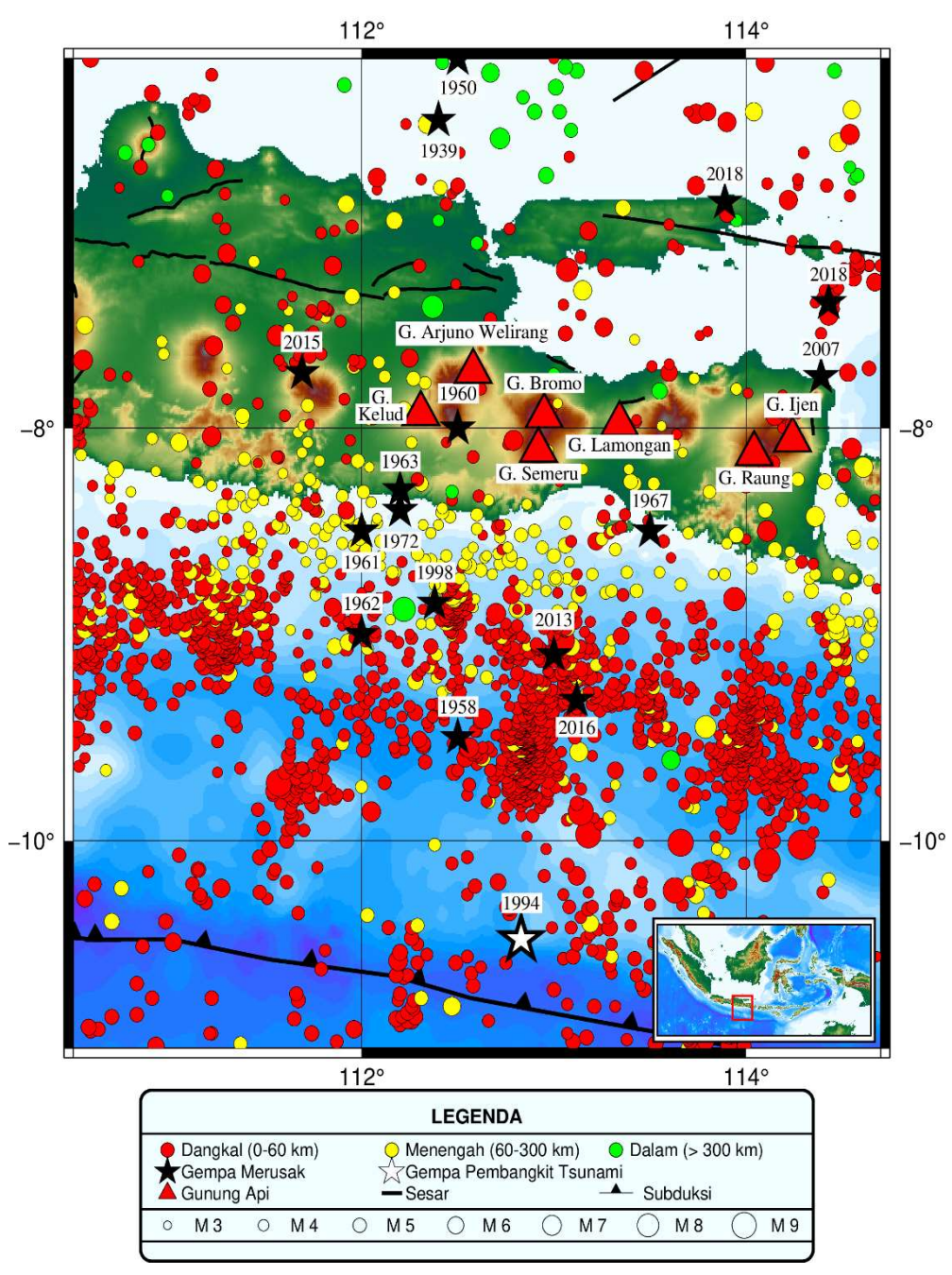

Gambar 1. Peta seismisitas Jawa Timur (BMKG, 2021).

Penelitian mengenai struktur kerak di daerah Jawa Timur sudah dilakukan oleh beberapa peneliti sebelumnya. Wölbern dan Rümpker (2016) melakukan penelitian kerak bumi di Jawa Tengah dan Timur menggunakan metode fungsi penerima dengan teknik stacking $H k$ pada jaringan seismik sementara MERAMEX (MERapi AMphibious
Experiment). Dari hasil penelitiannya didapatkan ketebalan kerak di Jawa Tengah dan Timur berkisar antara 27 hingga $39 \mathrm{~km}$. Bahri dkk. (2021) juga melakukan analisis fungsi penerima untuk menyelidiki sedimen dan struktur kerak bumi di Jawa Timur dan Kalimantan Timur. Hasil penelitiannya menunjukan bahwa variasi ketebalan sedimen 
di Jawa Timur antara 1-4 km dengan kedalaman kerak antara 20-40 km. Dengan metode ambient noise tomography, Martha dkk. (2017) melakukan penelitian struktur kerak atas Jawa Timur dan mendapatkan profil $v_{s}$ dan ketebalan sedimen di setiap zona geologi, dimana di Pegunungan Selatan didominasi $v_{\mathrm{s}}$ tinggi, Zona Kendeng didominiasi $v_{s}$ sangat rendah dan Zona Rembang mempunyai $v_{s}$ sedang. Penelitian perbandingan struktur kerak di setiap zona geologi di Jawa Barat dan Jawa Tengah sudah dilakukan oleh peneliti sebelumnya. Ariyanto dkk. (2018) melakukan analisis fungsi penerima menggunakan inversi algoritma Neighbourhood (NA) untuk menyelidiki struktur kerak bumi regional dan model kecepatan gelombang $S$ pada setiap unit geologi di wilayah Jawa Tengah (Zona Pegunungan Selatan, Zona Gunungapi Kuarter, Zona Depresi Tengah Jawa, dan Zona Dataran Aluvial Utara Jawa). Hasil penelitiannya menunjukkan bahwa ketebalan kerak wilayah Jawa Tengah bervariasi antara 22 hingga 38 km. Di Jawa Barat, Anggono dkk. (2020) meneliti kecepatan gelombang $S$ menggunakan analisis fungsi penerima di 11 stasiun broadband BMKG pada setiap zona geologi (Cekungan Jawa Barat Laut, Zona Bogor, dan Busur Pegunungan Selatan) dan mendapatkan hasil bahwa bahwa ketebalan sedimen Jawa bagian Barat bervariasi antara 1$2 \mathrm{~km}$ dan ketebalan kerak antara 25-32 km dengan nilai $v_{p} / v_{s}$ sekitar 1,69-1,78.

Pada penelitian ini dilakukan analisis fungsi penerima dari gempa teleseismik untuk menyelidiki struktur kerak bumi secara regional di bawah 6 stasiun seismik BMKG yang terletak pada 3 zona geologi utama di Jawa Timur. Dengan adanya penambahan jaringan stasiun BMKG yang lebih rapat dan mencakup beberapa zona geologi, hasil penelitian berupa ketebalan kerak bumi, model kecepatan gelombang $P$ dan $S$ yang lebih lokal di bawah stasiun dapat memberikan informasi lebih detail mengenai struktur kerak bumi pada setiap zona geologi di Jawa Timur. Adanya zona kecepatan rendah (low velocity zone), ketebalan sedimen, serta variasi ketebalan kerak sangat penting untuk menambah pemahaman mengenai aktivitas tektonik dan kaitannya dengan fenomena kebumian di daerah Jawa Timur. Selain itu, model kecepatan seismik yang lebih sesuai dengan kondisi lokal dari hasil penelitian ini diharapkan dapat digunakan untuk meningkatkan akurasi dalam penentuan hiposenter gempa bumi dan dapat digunakan untuk penelitian geofisika lainnya.

\section{TINJAUAN PUSTAKA}

\subsection{Fungsi Penerima}

Fungsi penerima adalah deret waktu yang memuat konversi gelombang $P$ ke $S(P s)$ yang dihasilkan ketika gelombang $P$ melewati lapisan diskontinuitas di bawah stasiun penerima (Gambar 2). Gelombang $P$ akan mengalami perubahan kecepatan yang signifikan karena pada lapisan tersebut terdapat perbedaan fisis dan kimia antara kerak bawah dan mantel bagian atas. Gelombang ini akan mengalami proses transmisi, konversi, refleksi, dan refraksi yang tergantung pada material diskontinuitas dan sudut insidensi gelombangnya. Fase-fase gelombang yang terkonversi ini digunakan untuk menentukan batas-batas lapisan di bawah stasiun penerima (Ligorría, 2000). 



Gambar 2. Diagram fungsi penerima. Fasa konversi $P s$ dan fasa-fasa pantulannya ( $P p P s$ dan $P p S s+P s P s)$ yang diterjemahkan dari bentuk suatu model lapisan bumi sederhana. Gambar dimodifikasi dari Ligorría (2000).

\subsection{Rotasi Fungsi Penerima}

Data seismik yang terekam pada seismogram secara umum menggunakan sistem koordinat ZNE yaitu vertikal (sumbu Z), horizontal Utara-Selatan (sumbu North South), dan horizontal Timur-Barat (sumbu East-West). Untuk mengisolasi energi agar fase-fase gelombang terlihat jelas dilakukan rotasi seismogram. Rotasi ini memanfaatkan back azimuth $(\gamma)$ dari gelombang tiba. Komponen vertikal $(Z)$ tidak dirotasi atau tetap, komponen N-S dirotasi menjadi radial $(R)$, dan komponen E-W dirotasi menjadi tangensial $(T)$. Sistem koordinat ini dikenal dengan sistem koordinat ZRT. Proses rotasi tersebut dilakukan menggunakan persamaan di bawah ini:

$$
\left[\begin{array}{l}
R \\
T \\
Z
\end{array}\right]=\left[\begin{array}{ccc}
-\cos \gamma & -\sin \gamma & 0 \\
\sin \gamma & -\cos \gamma & 0 \\
0 & 0 & 1
\end{array}\right]\left[\begin{array}{l}
N \\
E \\
Z
\end{array}\right]
$$

Dimana Z, N, E adalah komponen asli yaitu vertikal, Utara-Selatan, dan Timur-Barat; $\gamma$ adalah back azimuth gelombang datang; dan $\mathrm{Z}, \mathrm{R}, \mathrm{T}$ adalah komponen hasil rotasi yaitu vertikal, radial, dan tangensial (Stein \& Wysession, 2005).

\subsection{Estimasi Fungsi Penerima: Iterative Time Domain Deconvolution}

Iterative time-domain deconvolution merupakan teknik pemodelan kedepan (forward modelling) yaitu teknik memodelkan sinyal seismogram komponen radial dan tangensial dengan cara melakukan konvolusi berulang dari beberapa model wavelet $E(t)$ dengan seismogram komponen vertikal $Z(t)$ yang secara matematis dapat ditulis sebagai berikut:

$$
\begin{aligned}
R(t) & =E_{i R}(t) * Z(t) \\
T(t) & =E_{i T}(t) * Z(t)
\end{aligned}
$$

Dimana $\mathrm{R}(\mathrm{t})$ dan $\mathrm{T}(\mathrm{t})$ merupakan seismogram komponen radial dan tangensial dalam domain waktu. $\mathrm{E}_{\mathrm{i}}(\mathrm{t})$ merupakan fungsi respon struktur lokal yang diperoleh secara berulang pada komponen $\mathrm{R}$ dan $\mathrm{T}$. $\mathrm{Z}(\mathrm{t})$ adalah seismogram komponen vertikal dan ${ }^{*}$ merupakan simbol konvolusi. Fungsi respon struktur lokal $\mathrm{E}_{\mathrm{R}}(\mathrm{t})$ akan sebanding dengan $\mathrm{E}_{\mathrm{iR}}(\mathrm{t})$ jika misfit antara $\mathrm{R}(\mathrm{t})$ hasil observasi dan $\mathrm{R}(\mathrm{t})$ hasil sintetik minimum. Pada penelitian ini, kriteria fit yang digunakan adalah $\geq 90 \%$.

Pada perhitungan $\mathrm{E}_{\mathrm{iR}}(\mathrm{t})$ digunakan low pass Gaussian filter untuk mengisolasi gelombang dengan frekuensi rendah dan mengeliminasi gelombang dengan frekuensi tinggi. Persamaan filter tersebut yaitu:

$$
G(\omega)=\exp \left(\frac{-\omega}{4 a^{2}}\right)
$$

Dimana $\omega$ merupakan gain filter Gaussian dan $\alpha$ adalah parameter pengontrol lebar frekuensi filter Gaussian. Semakin tinggi nilai a $(>2,5)$ maka sinyal fungsi penerima akan semakin tajam apabila tidak terdapat derau (noise), namun apabila terdapat derau maka derau akan tetap terlihat. Semakin kecil nilai $\alpha(<1)$ 
maka semakin banyak derau yang tereliminasi namun sinyal fungsi penerima akan kurang terlihat. Beberapa penelitian sebelumnya merekomendasikan nilai $\alpha=1,5$ yaitu memfilter frekuensi tinggi diatas $0,75 \mathrm{~Hz}$ untuk memperoleh hasil sinyal fungsi penerima terbaik (Anggono dkk., 2020; Ligorría \& Ammon, 1999; Syuhada dkk., 2016).

\subsection{Inversi}

Teknik inversi digunakan dalam analisis fungsi penerima untuk mengestimasi struktur kerak bumi berupa model kecepatan gelombang. Prosedur teknik ini yaitu pertama diberikan model struktur kecepatan awal dari parameter struktur bawah permukaan. Selanjutnya model tersebut diperbaharui dengan pemodelan kedepan hingga misfit antara data observasi dan model minimum.

Julià dkk. (2000) merumuskan persamaan pemodelan kedepan fungsi penerima sebagai berikut:

$$
y=F[x]
$$

Dimana $y$ adalah data hasil pengolahan fungsi penerima berupa vektor berdimensi $\mathrm{N}$ dari titik-titik data, F[ ] adalah operator non linier yang memetakan vektor-vektor dalam ruang model menjadi vektor-vektor dalam ruang data, $x$ adalah vektor berdimensi $\mathrm{M}$ yang menggambarkan model. Persamaan 4 adalah persamaan non-linier yang dapat diinversi dengan linierisasi iteratif sebagaimana persamaan berikut:

$$
\begin{aligned}
& \delta y=\left.\nabla F\right|_{x_{n}} \cdot \delta X_{n} \\
& X_{n+1}=x_{n}+\delta x_{n}
\end{aligned}
$$

dimana $\delta x_{n}=x-x_{n}$ merupakan vektor koreksi model dan $\delta y=y-F\left[x_{n}\right]$ merupakan vektor data residu (Menke, 1989). Persamaan 4 dan 5 merupakan persamaan iteratif sehingga untuk memulai prosedurnya dibutuhkan model kecepatan awal. Pada penelitian ini model kecepatan awal yang digunakan adalah model kecepatan global AK135 (Kennett dkk., 1995).

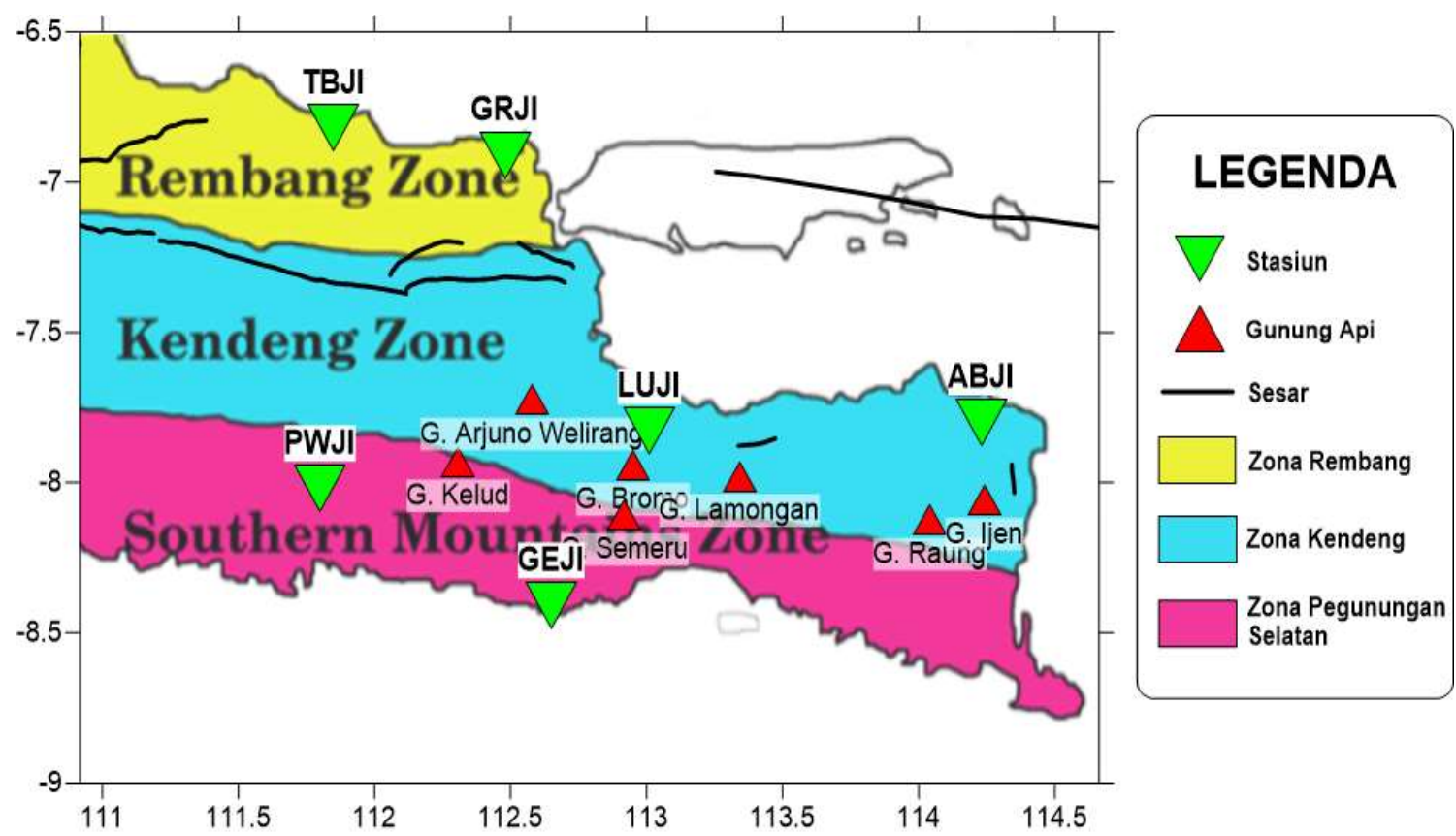

Gambar 3. Peta sebaran stasiun yang digunakan berdasarkan zona geologi utama di Jawa Timur (dimodifikasi dari Martha dkk. (2017).

3. 


\section{METODE PENELITIAN}

\subsection{Data}

Data yang digunakan pada penelitian ini merupakan data sinyal dari gempa teleseismik yang terekam pada jaringan seismograf BMKG. Jaringan seismograf yang digunakan merupakan seismometer broadband permanen tiga komponen sebanyak 6 sensor dengan batas koordinat $6,6^{\circ}-8,8^{\circ}$ LS dan $110,9^{\circ}-114,6^{\circ}$ BT yang tersebar pada 3 zona geologi utama di Jawa Timur. Koordinat stasiun yang akan digunakan disajikan pada Tabel 1 dan persebarannya dapat dilihat pada Gambar 3.

Kriteria gempa teleseismik yang digunakan pada penelitian ini yaitu memiliki jarak episenter antara $30^{\circ}-90^{\circ}$ dengan stasiun penerima dan kekuatan gempa $M \geq 6$ yang diseleksi menggunakan katalog gempa International Seismological Centre (ISC) (ISC, 2021). Sebaran episenter gempa teleseismik yang memenuhi kriteria dapat dilihat pada Gambar 3. Waveform dari gempa teleseismik tersebut diunduh melalui website BMKG pada laman https://geof.bmkg.go.id/webdc3/ berupa file dalam format mseed.

\subsection{Metode}

Metode pemrosesan data dilakukan dengan beberapa tahapan. Pertama adalah menyeleksi data parameter gempa teleseismik sesuai dengan kriteria sebelumnya. Data waveform tersebut diunduh dengan rentang 1 menit sebelum fase gelombang $P$ dan 5 menit setelahnya. Data dalam format mseed tersebut diubah menjadi format fullseed dengan menambahkan parameter respon instrumen. Selanjutnya data fullseed diekstrak ke dalam format SAC menggunakan perangkat lunak rdseed. Sinyal gempabumi dipilih secara manual untuk mendapatkan rekaman dengan signal to noise ratio (SNR) tinggi dan fase awal gelombang $P$ yang terbaca dengan jelas. Dalam pemrosesan sinyal teleseismik digunakan perangkat lunak CPS (Computer
Programs in Seismology) yang dikembangkan oleh Herrmann (2013). Selanjutnya, seismogram dilakukan koreksi baseline dengan mensubtraksi rata-ratanya. Untuk mengisolasi fase konversi $P s$, dilakukan rotasi komponen seismogram NS (Utara-Selatan) dan EW (Timur-Barat) ke arah komponen radial dan tangensial. Sinyal kemudian diseleksi lebar window yang diinginkan mulai dari $10 \mathrm{~s}$ sebelum dan $50 \mathrm{~s}$ setelah waktu datang gelombang $P$.

Selanjutnya adalah menghitung fungsi penerima komponen radial dan tangensial dengan iterative time domain deconvolution dengan 500 iterasi dengan teknik yang dikembangkan oleh Ligorría \& Ammon (1999). Hasil kalkulasi fungsi penerima yang mempunyai sinyal dengan kriteria fit sebesar $90 \%$ atau lebih dari fungsi penerima observasi akan digunakan untuk analisis selanjutnya. Sinyal fungsi penerima komponen radial yang diperoleh dari proses dekonvolusi selanjutnya diplot sebagai fungsi back azimuth terhadap waktu untuk mengidentifikasi struktur kerak berdasarkan fase-fase gelombang. Setelah itu, dilakukan proses stacking. Proses ini dilakukan untuk memperkuat sinyal utama fungsi penerima dan meminimalisasi backround noise. Model kecepatan gelombang $P$ dan $S$ dari fungsi penerima diperoleh menggunakan program CPS dengan cara menginput fungsi penerima komponen radial dan model kecepatan awal yang terdapat pada program CPS yaitu model kecepatan global AK135. Selanjutnya dilakukan inversi hingga diperoleh model kecepatan gelombang $P$ dan $S$ di bawah stasiun penerima. Untuk mengidentifikasi kedalaman per lapisan dan pencitraan struktur kompleks yang kuat, dilakukan migrasi sinyal fungsi penerima pada domain waktu ke domain kedalaman dengan menggunakan model kecepatan global AK135. Proses migrasi fungsi penerima penelitian ini menggunakan program SplitRFLab yang dikembangkan oleh Xu dkk. (2016). 

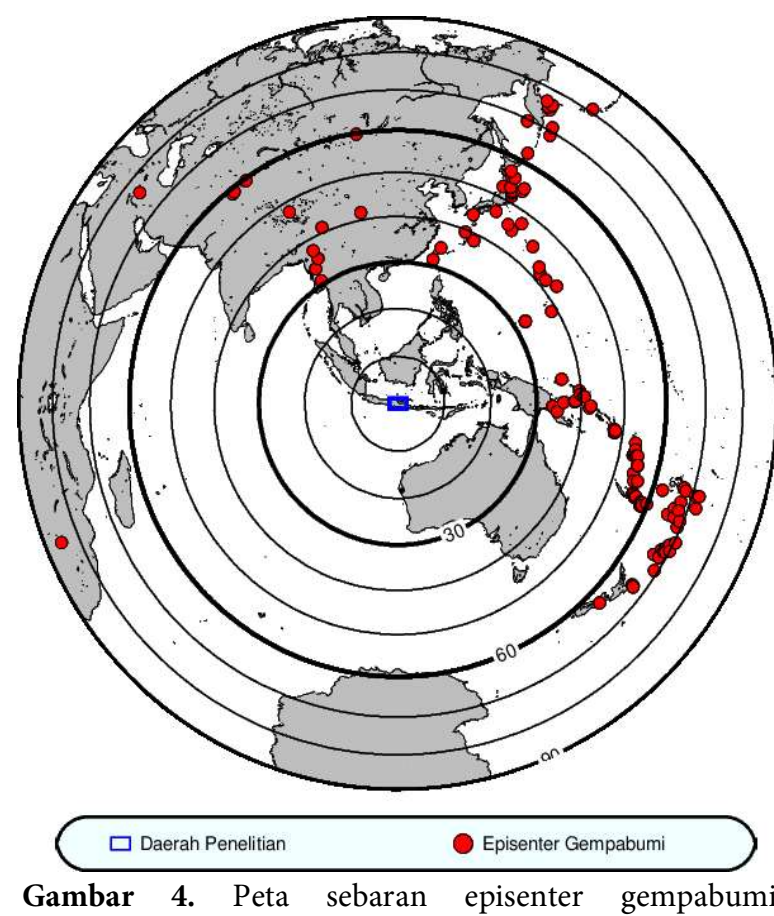

teleseismik yang digunakan.

Tabel 1. Data Stasiun yang digunakan.

\begin{tabular}{cccc}
\hline Zona & Kode Stasiun & Lintang $\left(^{\circ}\right)$ & Bujur $\left(^{\circ}\right)$ \\
\hline \multirow{2}{*}{ Rembang } & TBJI & $-6,82$ & 111,85 \\
& GRJI & $-6,91$ & 112,48 \\
\hline \multirow{2}{*}{ Kendeng } & LUJI & $-7,83$ & 113,01 \\
& ABJI & $-7,80$ & 114,23 \\
\hline Pegunungan & PWJI & $-8,02$ & 111,80 \\
Selatan & GEJI & $-8,41$ & 111,65 \\
\hline
\end{tabular}

\section{HASIL DAN PEMBAHASAN}

Struktur kerak dari analisis fungsi penerima teleseismik pada 6 stasiun seismik BMKG dilakukan berdasarkan pengelompokan zona geologi utama wilayah Jawa Timur yaitu Zona Rembang, Zona Kendeng, dan Zona Pegunungan Selatan (Smyth, 2005; Van Bemmelen, 1949).

\subsection{Zona Rembang}

Struktur kerak pada Zona Rembang diwakili oleh 2 stasiun seismik broadband BMKG yaitu Stasiun Tambakboyo (TBJI) yang terletak pada koordinat $6,82^{\circ}$ LS $111,85^{\circ}$ BT dan Stasiun Gresik (GRJI) yang terletak pada koordinat $6,91^{\circ}$ LS $112,48^{\circ}$ BT. Pada Gambar 5(a) ditampilkan 38 event fungsi penerima teleseismik komponen radial dari beberapa back azimuth serta hasil stacking pada stasiun TBJI dan Gambar 5(b) menunjukan 45 fungsi penerima pada stasiun GRJI dengan nilai fit $\geq$ 90\%. Pada kedua stasiun, pola sinyal fungsi penerima terlihat memiliki bentuk yang identik, dimana menandakan adanya kemiripan struktur per lapisan di bawah 2 stasiun di Zone Rembang tersebut. Fase kedatangan gelombang $P$ langsung pada kedua stasiun terlihat pada 0 s. Selanjutnya fase konversi gelombang $P$ ke gelombang $S(P s)$ dari lapisan Moho teramati sekitar pada waktu 3 s. Amplitudo pada fase ini lebih kecil dibandingkan pada fase sebelumnya yang diduga merupakan fase $P$ s yang terkonversi oleh lapisan sedimen dangan batuan dasar (fase $P b S$ ) pada waktu 2 s. Amplitudo yang lebih besar pada fase $P b S$ disebabkan oleh kontras kecepatan antara batuan dasar dengan 
sedimen tebal dibawah stasiun, sebagaimana ditemukan pada hasil penelitian Yu dkk. (2015) dan Ariyanto dkk. (2021). Adanya fase $\mathrm{PbS}$ tersebut dapat terlihat lebih jelas dengan menerapkan nilai lebar filter Gaussian $5(\alpha=5)$, dimana fase-fasenya lebih tajam sebagaimana dapat dilihat pada Gambar 6. Pada Gambar 6 tersebut terlihat jelas fase-fase fungsi penerima secara berturut-turut, yaitu fase $P p$ pada $0 \mathrm{~s}$, fase $P b S$ pada $\sim 2$ s, dan fase $P s$ Moho pada $\sim 3 \mathrm{~s}$. Selanjutnya terdapat fase gelombang dengan polaritas negatif ganda pada waktu 4-8 s pada stasiun TBJI dan 6-9 s pada stasiun GRJI yang kemungkinan berasosiasi dengan zona kecepatan rendah di bawah zona Rembang sebagaimana ditemukan oleh Martha dkk. (2017). Penemuan ini merupakan hal yang menarik yang memerlukan studi lebih lanjut. Hasil inversi fungsi penerima berupa model kecepatan gelombang $P$ dan gelombang $S$ dari permukaan hingga kedalaman $100 \mathrm{~km}$ serta hasil fitting antara model dan sinyal observasi pada stasiun TBJI ditunjukan oleh Gambar 7. Pada Gambar 7 tersebut terlihat bahwa sinyal fungsi penerima observasi yang digambarkan oleh garis berwarna biru memiliki kecocokan sebesar $85,09 \%$ dengan sinyal model yang digambarkan oleh garis berwarna merah. Pada stasiun TBJI ini, model kecepatan gelombang $P$ di dekat permukaan memiliki nilai minimum $\sim 2,3 \mathrm{~km} / \mathrm{s}$ dan mengalami kenaikan secara gradual sampai kedalaman $20 \mathrm{~km}$. Pada kedalaman 20-24 km, kecepatan gelombang $P$ meningkat menjadi menjadi $\sim 8,7 \mathrm{~km} / \mathrm{s}$. Pada kedalaman ini diperkirakan adanya keberadaan lapisan Moho. Selanjutnya kecepatan turun menjadi $\sim 6,1 \quad \mathrm{~km} / \mathrm{s}$ di kedalaman $\sim 52 \mathrm{~km}$ yang menunjukkan adanya zona kecepatan rendah kemudian naik kembali hingga kecepatan mencapai $\sim 8,3 \mathrm{~km} / \mathrm{s}$.

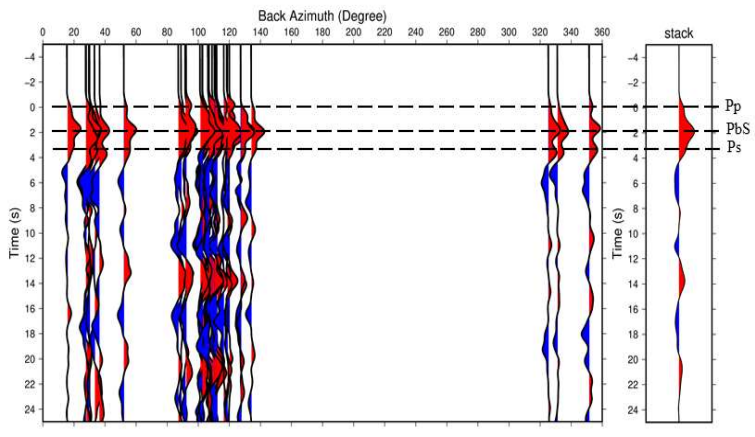

(a)

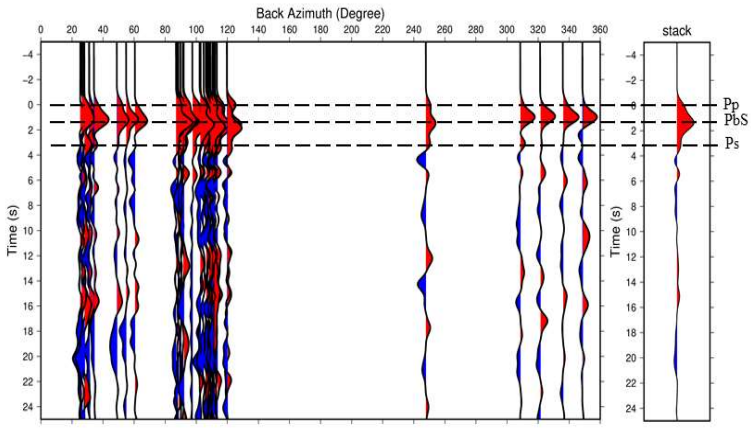

(b)

Gambar 5. Hasil fungsi penerima yang diplot berdasarkan back azimuth (kiri) dan hasil stacking (kanan) pada stasiun TBJI (a) dan stasiun GRJI (b). 
Sementara itu, pada grafik kecepatan gelombang $S$ stasiun TBJI menunjukkan nilai minimum di bawah $2 \mathrm{~km} / \mathrm{s}$ dari permukaan hingga kedalaman $4 \mathrm{~km}$. Kecepatan gelombang $S$ yang rendah ini diidentifikasi sebagai adanya lapisan sedimen. Kecepatan gelombang kemudian meningkat secara gradual hingga $\sim 4,8 \mathrm{~km} / \mathrm{s}$ pada kedalaman $\sim 22 \mathrm{~km}$. Selanjutnya kecepatan gelombang menurun secara perlahan hingga kecepatan $\sim 3,3 \mathrm{~km} / \mathrm{s}$ di kedalaman $\sim 55 \mathrm{~km}$ dan meningkat kembali hingga $\sim 4,6 \mathrm{~km} / \mathrm{s}$.

Model kecepatan gelombang $P$ dan gelombang $S$ dari permukaan hingga kedalaman $100 \mathrm{~km}$ serta hasil fitting antara sinyal observasi dan model pada stasiun GRJI ditunjukan oleh Gambar 8. Nilai kecocokan antara model (garis merah) dan observasi (garis biru) di bawah stasiun ini sebesar 94,35\%. Pada grafik kecepatan gelombang $P$ di bawah stasiun GRJI memiliki nilai minimum $\sim 2,3 \mathrm{~km} / \mathrm{s}$ dan nilai maksimum $\sim 9,0 \mathrm{~km} / \mathrm{s}$. Pada lapisan permukaan sampai kedalaman 14 $\mathrm{km}$, kecepatan gelombang naik secara perlahan-lahan dari $\sim 2,3 \mathrm{~km} / \mathrm{s}$ menjadi $\sim 8,1$ $\mathrm{km} / \mathrm{s}$. Selanjutnya kecepatan gelombang turun dari $\sim 8,1 \mathrm{~km} / \mathrm{s}$ hingga $\sim 6,7 \mathrm{~km} / \mathrm{s}$ pada kedalaman $\sim 34 \mathrm{~km}$ dan naik kembali hingga kecepatan mencapai $\sim 9,0 \mathrm{~km} / \mathrm{s}$.

Model kecepatan gelombang $S$ pada stasiun GRJI memiliki nilai kecepatan gelombang $S$ yang rendah yaitu kurang dari $\sim 2,0 \mathrm{~km} / \mathrm{s}$ pada kedalaman dangkal kurang dari $2 \mathrm{~km}$. Nilai kecepatan gelombang $S$ yang rendah dari permukaan ini mengidentifikasi adanya lapisan sedimen lunak di bawah stasiun ini. Kecepatan gelombang $S$ selanjutnya meningkat hingga $\sim 4,5$ di kedalaman $\sim 14 \mathrm{~km}$, kemudian turun secara perlahan hingga $\sim 3,7 \mathrm{~km} / \mathrm{s}$ pada kedalaman $\sim 34 \mathrm{~km}$. Setelah itu, kecepatan terus meningkat hingga $\sim 5,0 \mathrm{~km} / \mathrm{s}$.

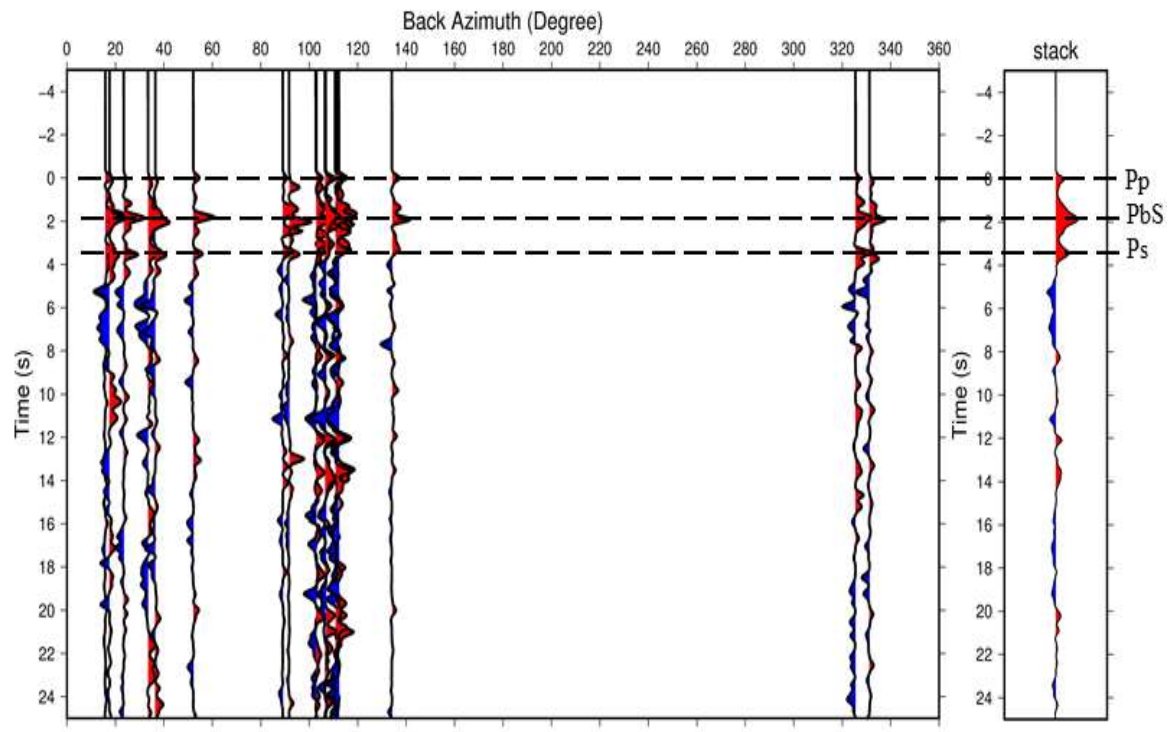

Gambar 6. Hasil sinyal fungsi penerima pada stasiun TBJI dengan nilai lebar filter Gaussian $5(\alpha=5)$. 




Gambar 7. Model kecepatan gelombang $P$ (panel kiri atas) dan gelombang $S$ (panel kanan atas) di bawah stasiun TBJI. Garis biru merupakan hasil akhir model kecepatan, garis merah merupakan model kecepatan awal, dan garis warna-warni merupakan proses iterasi model kecepatan. Panel bagian bawah merupakan fitting fungsi penerima observasi dan model digambarkan oleh garis biru dan merah.

Pada model kecepatan gelombang $P$ dan $S$, kenaikan kecepatan yang signifikan pada diskontinuitas Moho tidak teramati secara jelas, sehingga untuk mengidentifikasi lapisan diskontinuitas Moho di bawah stasiun dilakukan migrasi fungsi penerima ke kedalaman sebagaimana yang ditunjukkan oleh Gambar 9. Pada stasiun TBJI, kedalaman Moho diperkirakan pada kedalaman sekitar 25$28 \mathrm{~km}$ yang ditandai dengan garis hitam putusputus sebagaimana yang ditunjukkan oleh Gambar 9(a). Sementara itu, pada stasiun GRJI, kedalaman Moho diestimasi pada kedalaman 23-27 km yang ditandai dengan garis hitam putus-putus ditampilkan oleh Gambar 9(b). Adanya konversi fase $P b S$ yang ditandai dengan garis kuning putus-putus pada kedua stasiun ini juga terlihat cukup jelas.

Ketebalan sedimen di bawah stasiun TBJI teramati hingga kedalaman $12-15 \mathrm{~km}$, sedangkan pada stasiun GRJI sekitar 8-10 km. Ketebalan sedimen yang lebih tebal pada hasil migrasi fungsi penerima dibandingkan dengan model kecepatan gelombang $S$ diduga karena semakin dalam kedalaman, lapisan sedimen semakin terkonsolidasi sehingga kecepatan gelombangnya semakin besar. 



Gambar 8. Model kecepatan gelombang $P$ (panel kiri atas) dan gelombang $S$ (panel kanan atas) di bawah stasiun GRJI. Garis biru merupakan hasil akhir model kecepatan, garis merah merupakan model kecepatan awal, dan garis warna-warni merupakan proses iterasi model kecepatan. Panel bagian bawah merupakan fitting fungsi penerima observasi dan model digambarkan oleh garis biru dan merah.



Gambar 9. Hasil migrasi fungsi penerima ke kedalaman di stasiun TBJI (a) dan stasiun GRJI (b) yang berada di Zona Rembang. Kedalaman lapisan Moho ditandai dengan garis hitam putus-putus, sedangkan kedalaman basement ditunjukan dengan garis kuning putus-putus.

\subsection{Zona Kendeng}

Pada zona Kendeng, analisis struktur kerak bumi diwakili oleh 2 stasiun seismik broadband BMKG yaitu Stasiun Lumbang (LUJI) pada koordinat $7,83^{\circ}$ LS dan $113,01^{\circ} \mathrm{BT}$ serta Stasiun Asem Bagus, Situbondo (ABJI) pada koordinat $7,80^{\circ}$ LS dan $114,23^{\circ}$ BT. Berbeda dengan zona sebelumnya, pada zona ini sinyal fungsi penerima kedua stasiun tersebut memiliki pola yang tidak sama. 
Pada Gambar 10 ditampilkan 19 sinyal fungsi penerima komponen radial pada stasiun LUJI dari beberapa back azimuth serta hasil stacking sinyal fungsi penerima. Pada stasiun ini kriteria sinyal fungsi penerima yang digunakan memiliki nilai fit hasil dekonvolusi sebesar $85 \%$. Hal ini dilakukan karena data yang tersedia hanya pada tahun 2020-2021. Fase gelombang $P$ langsung (direct $P / P p$ ) pada stasiun ini teramati pada $\sim 1$ s. Hal ini menunjukan bahwa terdapat delay pada fase $P p$ di stasiun LUJI yang mengakibatkan fase ini baru tiba pada detik ke 1. Delay time pada fase $P p$ disebabkan karena adanya lapisan sedimen dengan kecepatan sangat rendah di bawah permukaan yang mengakibatkan interval waktu fase $P s$ dari sedimen $(P b S)$ sangat kecil sehingga amplitudo fase $P b S$ bercampur dengan fase $P p$ (Chen \& Niu, 2016; Yu dkk., 2015). Hal ini akan teramati secara jelas apabila nilai lebar filter Gaussian ditingkatkan menjadi $5 \quad(\alpha=5)$ sebagaimana yang ditunjukkan oleh Gambar 11. Pada Gambar 11 terlihat bahwa terdapat 2 fase fungsi penerima sebelum $1 \mathrm{~s}$, yaitu fase $P p$ pada sekitar detik ke 0 dan fase $P b S$ pada detik ke 1 . Perbedaan waktu tiba yang sangat kecil pada kedua fase ini mengakibatkan kedua fase tersebut bercampur dan terlihat seolah-olah fase Pp mengalami delay. Fase selanjutnya adalah fase konversi gelombang $P$ ke gelombang $S$ yang berasal dari lapisan Moho terlihat pada waktu $\sim 2,5 \mathrm{~s}$.
Hasil sinyal fungi penerima komponen radial dari beberapa back azimuth serta hasil stacking pada stasiun ABJI dari 42 event gempa bumi dengan fit $\geq 90 \%$ ditunjukkan oleh Gambar 12. Fase gelombang $P$ langsung (direct $P / P p$ ) pada stasiun ABJI terlihat pada 0 s. Kemudian fase gelombang $P$ yang terkonversi dari lapisan Moho teramati pada waktu $\sim 2 \mathrm{~s}$.

Hasil inversi sinyal fungsi penerima berupa model kecepatan gelombang $P$ dan gelombang $S$ dari permukaan hingga kedalaman $100 \mathrm{~km}$ serta hasil fitting model dengan sinyal hasil observasi pada stasiun LUJI ditunjukkan oleh Gambar 13. Pada Gambar 13 tersebut terlihat bahwa sinyal fungsi penerima hasil observasi yang digambarkan oleh garis berwarna biru memiliki kecocokan sebesar 90,04\% dengan sinyal model yang digambarkan oleh garis berwarna merah. Pada grafik kecepatan gelombang $P$ di bawah stasiun LUJI memiliki nilai $\sim 2,1 \mathrm{~km} / \mathrm{s}$ di dekat permukaan dan meningkat secara gradual hingga kedalaman $\sim 16 \mathrm{~km}$ hingga $\sim 7,8 \mathrm{~km} / \mathrm{s}$. Pada kedalaman ini diperkirakan terjadi perubahan batuan dari kerak bawah ke mantel atas dengan kecepatan yang lebih tinggi. Pada kedalaman $\sim 16-44 \mathrm{~km}$ perubahan terjadi secara fluktuatif. Selanjutnya kecepatan gelombang $P$ naik secara perlahan hingga kecepatan $\sim 9,6 \mathrm{~km} / \mathrm{s}$ pada kedalaman $\sim 70 \mathrm{~km}$. Kemudian kecepatan sedikit mengalami penurunan dan selanjutnya cenderung stabil pada kecepatan $\sim 8,7 \mathrm{~km} / \mathrm{s}$ pada bagian mantel atas. 


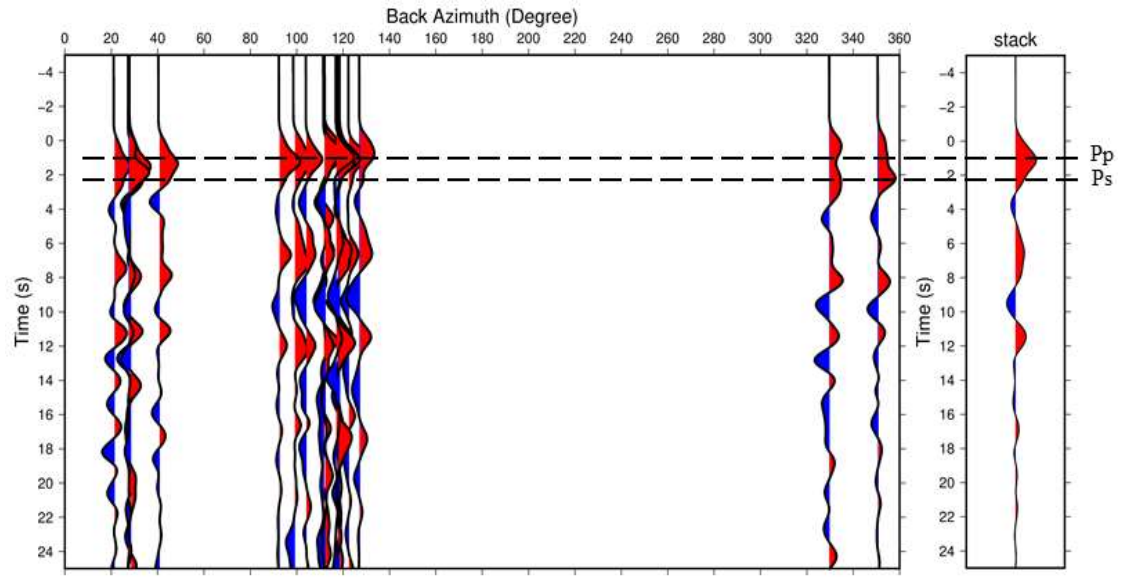

Gambar 10. Hasil fungsi penerima yang diplot berdasarkan back azimuth (kiri) dan hasil stacking (kanan) pada stasiun LUJI.

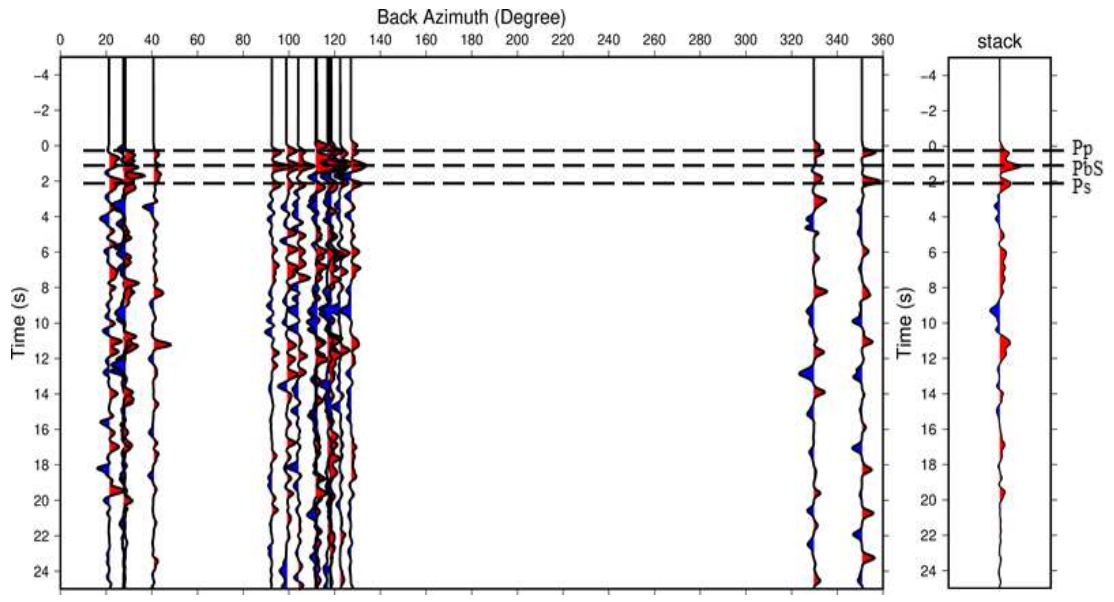

Gambar 11. Hasil sinyal fungsi penerima pada stasiun LUJI dengan nilai lebar filter Gaussian $5(\alpha=5)$.

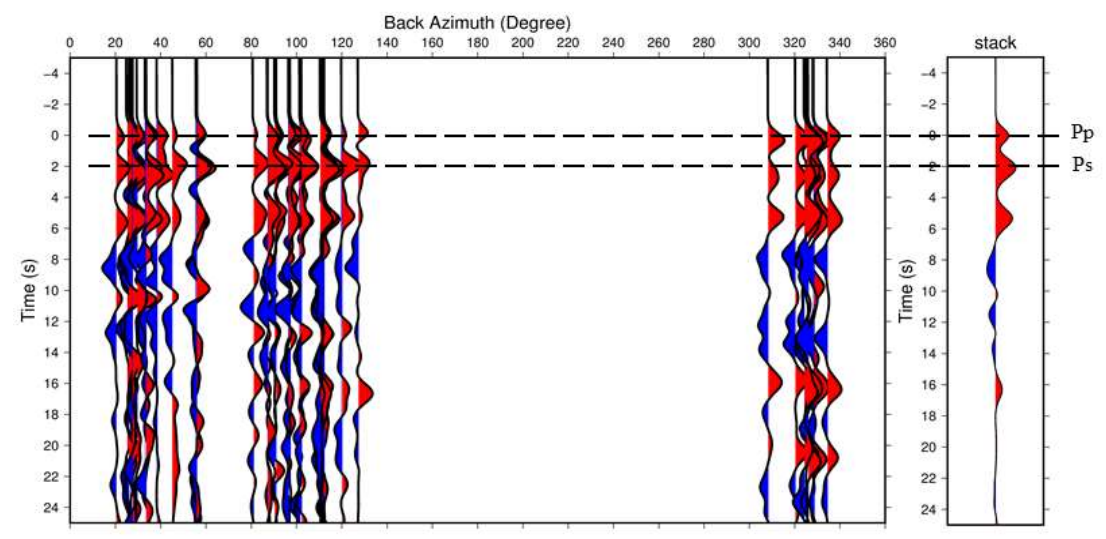

Gambar 12. Hasil fungsi penerima yang diplot berdasarkan back azimuth (kiri) dan hasil stacking (kanan) pada stasiun ABJI. 




Gambar 13. Model kecepatan gelombang $P$ (panel kiri atas) dan gelombang $S$ (panel kanan atas) di bawah stasiun LUJI. Garis biru merupakan hasil akhir model kecepatan, garis merah merupakan model kecepatan awal, dan garis warna-warni merupakan proses iterasi model kecepatan. Panel bagian bawah merupakan fitting fungsi penerima observasi dan model digambarkan oleh garis biru dan merah.

Model kecepatan gelombang $S$ pada stasiun LUJI memiliki nilai sangat rendah sebesar $\sim 1,2$ $\mathrm{km} / \mathrm{s}$ di permukaan hingga kedalaman $2 \mathrm{~km}$. Kecepatan gelombang $S$ yang rendah ini mengidentifikasi adanya lapisan sedimen lunak. Kecepatan gelombang kemudian meningkat secara perlahan hingga $\sim 4,4 \mathrm{~km} / \mathrm{s}$ sekitar pada kedalaman $16 \mathrm{~km}$. Kecepatan gelombang $S$ selanjutnya mengalami perubahan secara fluktuatif pada kedalaman 16-44 km. Kemudian kecepatan naik secara perlahan hingga kecepatan $\sim 5,3 \mathrm{~km} / \mathrm{s}$ pada kedalaman $\sim 65 \mathrm{~km}$.

Model kecepatan gelombang $P$ dan gelombang $S$ dari permukaan hingga kedalaman $100 \mathrm{~km}$ serta hasil fitting antara sinyal observasi dan model pada stasiun ABJI ditunjukan oleh Gambar 14. Nilai kecocokan antara model (garis merah) dan sinyal hasil observasi (garis biru) di bawah stasiun ini sebesar 92,93\%. Pada profil kecepatan gelombang $P$ di bawah stasiun ABJI memiliki nilai sekitar 2,8 km/s pada lapisan dari permukaan dan meningkat secara gradual hingga kedalaman $\sim 20 \mathrm{~km}$ hingga $\sim 7,1 \mathrm{~km} / \mathrm{s}$. Kecepatan gelombang $P$ kemudian turun hingga sekitar $6,4 \mathrm{~km} / \mathrm{s}$ pada kedalaman $\sim 22$ $30 \mathrm{~km}$ dan naik kembali hingga $8,4 \mathrm{~km} / \mathrm{s}$ di kedalaman $\sim 44 \mathrm{~km}$.

Model kecepatan gelombang $S$ pada stasiun ABJI memiliki nilai kecepatan gelombang $S$ yang rendah yaitu kurang dari $2,0 \mathrm{~km} / \mathrm{s}$ pada kedalaman dangkal kurang dari $6 \mathrm{~km}$. Nilai kecepatan gelombang $S$ yang rendah dari permukaan ini mengidentifikasi adanya lapisan sedimen lunak di bawah stasiun ini. Kecepatan gelombang $S$ kemudian meningkat hingga sekitar $3,9 \mathrm{~km} / \mathrm{s}$ di kedalaman $\sim 18 \mathrm{~km}$ dan turun kembali pada kedalaman 20-30 km. Setelah itu, kecepatan meningkat hingga $\sim 4,7$ $\mathrm{km} / \mathrm{s}$ sekitar di kedalaman $42 \mathrm{~km}$. 
Untuk menganalisis diskontinuitas Moho di bawah stasiun dilakukan migrasi fungsi penerima ke kedalaman sebagaimana yang ditunjukkan oleh Gambar 15. Diskontinuitas Moho pada stasiun LUJI dan ABJI diperkirakan memiliki kedalaman yang sama yaitu pada $18-20 \mathrm{~km}$ yang ditandai dengan garis hitam putus-putus (15). Pada stasiun LUJI (Gambar 15 (a)) keberadaan lapisan Moho terlihat samar-samar akibat adanya fase yang lebih besar yang diduga akibat lapisan sedimen di bawah stasiun. Oleh karena itu, untuk meningkatkan resolusi hasil migrasi fungsi penerima ke kedalaman, dilakukan pula migrasi pada fungsi penerima dengan nilai lebar filter Gaussian 5 (Gambar 16). Pada Gambar 16 tersebut kedalaman Moho di bawah stasiun LUJI teramati dengan jelas pada kedalaman 18-20 km yang ditandai dengan garis hitam putus-putus.

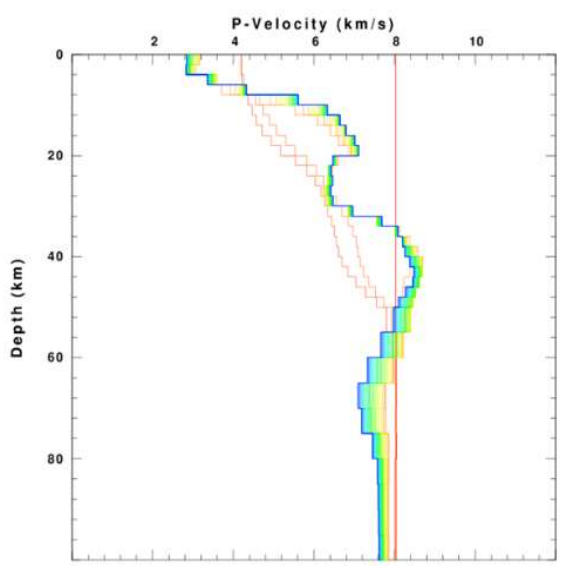

Pada hasil migrasi fungsi penerima ke kedalaman di bawah stasiun LUJI yang ditunjukan oleh Gambar 15 (a) dan Gambar 16, fase konversi $P s$ yang berasal dari sedimen (fase $P b S$ ) teramati pada kedalaman $8-10 \mathrm{~km}$ yang ditandai dengan garis kuning putusputus. Fase ini mengidentifikasi ketebalan lapisan sedimen di bawah stasiun LUJI. Hasil ini sedikit berbeda dengan hasil perkiraan lapisan sedimen berdasarkan model kecepatan gelombang $S$, dimana pada hasil migrasi fungsi penerima lapisan sedimen lebih tebal beberapa $\mathrm{km}$ diduga dikarenakan semakin dalam kedalaman maka lapisan sedimen akan terkonsolidasi sehingga kecepatan gelombangnya semakin besar. Hasil ketebalan sedimen di bawah stasiun ini sesuai dengan hasil penelitian dari Martha dkk. (2017) yang menyatakan bahwa ketebalan sedimen pada Cekungan Kendeng sekitar 8-10 km.

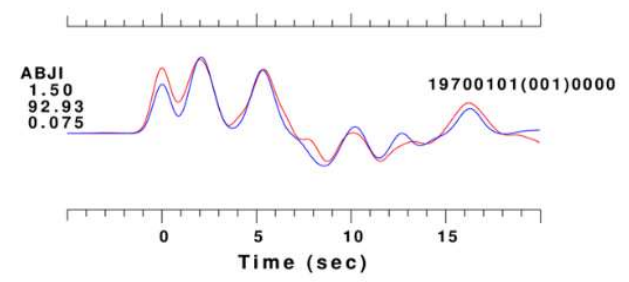

Gambar 14. Model kecepatan gelombang $P$ (panel kiri atas) dan gelombang $S$ (panel kanan atas) di bawah stasiun ABJI. Garis biru merupakan hasil akhir model kecepatan, garis merah merupakan model kecepatan awal, dan garis warna-warni merupakan proses iterasi model kecepatan. Panel bagian bawah merupakan fitting fungsi penerima observasi dan model digambarkan oleh garis biru dan merah. 



(b)

Gambar 15. Hasil migrasi fungsi penerima ke kedalaman di stasiun LUJI (a) dan stasiun ABJI (b) yang berada di Zona Kendeng. Kedalaman lapisan Moho ditandai dengan garis hitam putus-putus, sedangkan kedalaman basement ditunjukan dengan garis kuning putus-putus.

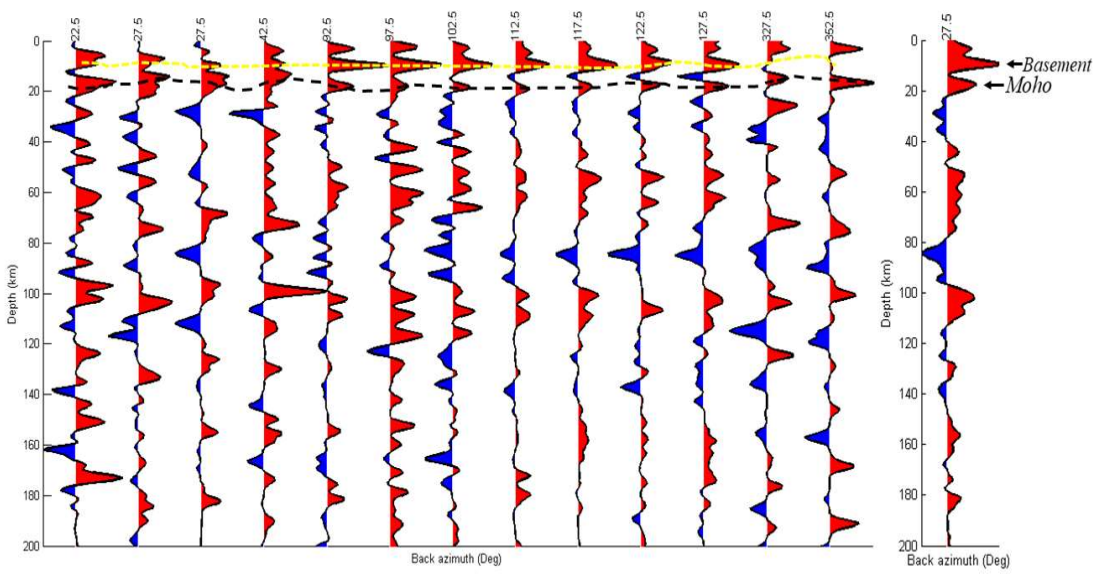

Gambar 16. Hasil migrasi fungsi penerima ke kedalaman pada stasiun LUJI dengan lebar filter Gaussian $5(\alpha=5)$. Kedalaman lapisan Moho ditandai dengan garis hitam putus-putus, sedangkan kedalaman basement ditunjukan dengan garis kuning putus-putus. 


\subsection{Zona Pegunungan Selatan}

Zona Pegunungan Selatan diwakili oleh 2 stasiun seismik broadband BMKG yang terletak di Selatan Jawa Timur yaitu Stasiun Pagerwojo (PWJI) yang terletak pada $8,02^{\circ} \mathrm{LS}$ dan $111,80^{\circ}$ BT serta Stasiun Gedangan (GEJI) yang terletak pada koordinat $8,41^{\circ}$ LS dan $111,65^{\circ}$ BT. Gambar 17 menampilkan hasil pengolahan fungsi penerima komponen radial dari beberapa back azimuth dan hasil stacking pada kedua stasiun ini. Pada stasiun PWJI ditampilkan 38 trace fungsi penerima dengan fit $\geq 90 \%$ (Gambar 17 (a)) dan pada stasiun GEJI ditampilkan 25 trace fungsi penerima dengan fit $\geq 85 \%$ (Gambar 17(b)). Pada stasiun GEJI kriteria nilai fit hasil dekonvolusi sinyal fungsi penerima diturunkan menjadi 85\% dikarenakan data yang tersedia hanya pada tahun 2020-2021.

Pada Gambar 17 terlihat bahwa kedua stasiun ini memiliki struktur sinyal yang sama. Fase $P$ langsung $(P p /$ direct $P)$ pada kedua stasiun tidak tepat di $0 \mathrm{~s}$, namun terjadi delay sekitar 0,5 s. Delay time ini diduga karena adanya lapisan tipis sedimen di bawah kedua stasiun sehingga fase $P s$ dari sedimen bercampur dengan fase $P p$ (Chen \& Niu, 2016; Yu et al., 2015). Selanjutnya fase konversi $P$ ke $S(P s)$ yang berasal dari lapisan Moho teramati pada waktu $\sim 4 \mathrm{~s}$ pada stasiun PWJI dan $\sim 4,5 \mathrm{~s}$ pada stasiun GEJI.

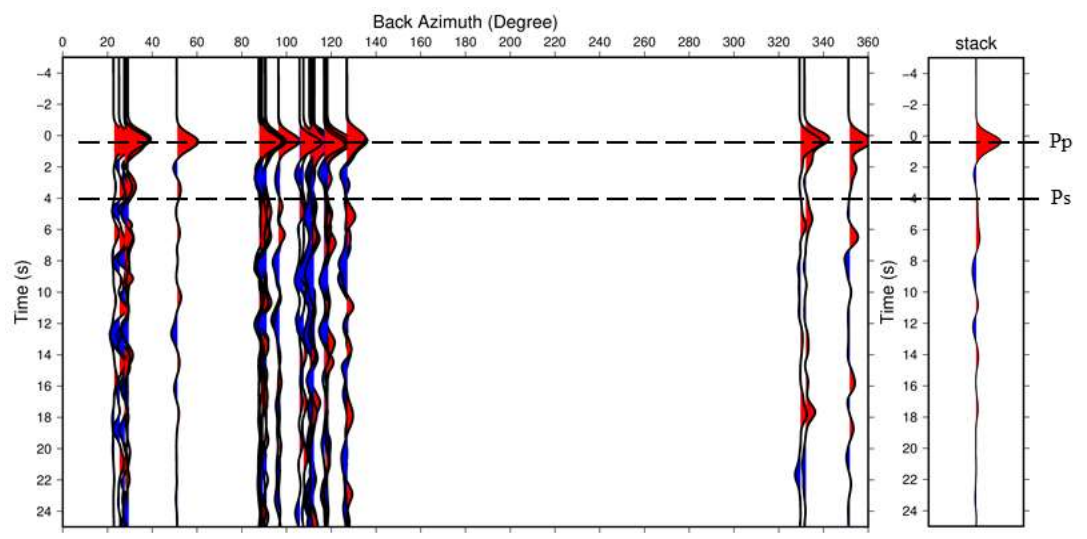

(a)

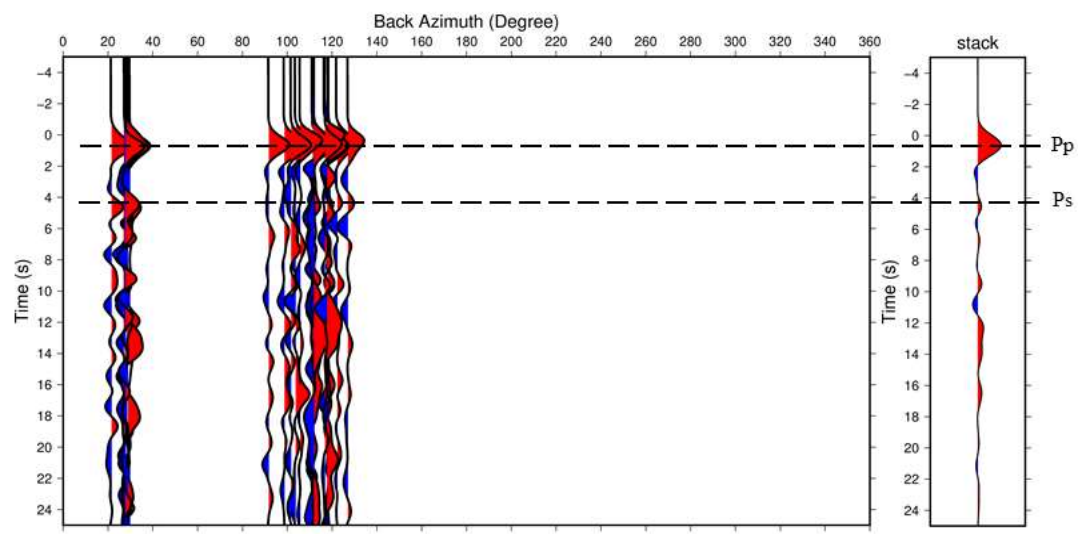

(b)

Gambar 17. Hasil fungsi penerima yang diplot berdasarkan back azimuth (kiri) dan hasil stacking (kanan) pada stasiun PWJI (a) dan stasiun GEJI (b). 
Hasil inversi fungsi penerima berupa model kecepatan gelombang $P$ dan gelombang $S$ dari permukaan hingga kedalaman $100 \mathrm{~km}$ serta hasil fitting antara sinyal hasil inversi dan sinyal observasi pada stasiun PWJI ditunjukan oleh Gambar 18. Pada gambar tersebut terlihat bahwa sinyal fungsi penerima hasil observasi yang digambarkan oleh garis berwarna biru memiliki kecocokan sebesar 94,28\% dengan sinyal model yang digambarkan oleh garis berwarna merah. Pada stasiun ini model kecepatan gelombang $P$ dari permukaan hingga kedalaman $\sim 10 \mathrm{~km}$ terlihat mengalami kenaikan dari sekitar $3,6 \mathrm{~km} / \mathrm{s}$ menjadi $\sim 6,4$ $\mathrm{km} / \mathrm{s}$. Pada kedalaman $\sim 16-34 \mathrm{~km}$ kecepatan gelombang $P$ mengalami perubahan secara fluktuatif. Pada kedalaman $34-36 \mathrm{~km}$ terlihat kenaikan gelombang $P$ cukup signifikan yang diidentifikasi sebagai lapisan Moho. Kemudian kecepatan gelombang $P$ naik secara perlahan hingga $\sim 8,2 \mathrm{~km} / \mathrm{s}$ pada kedalaman sekitar 55 $\mathrm{km}$ pada mantel atas.

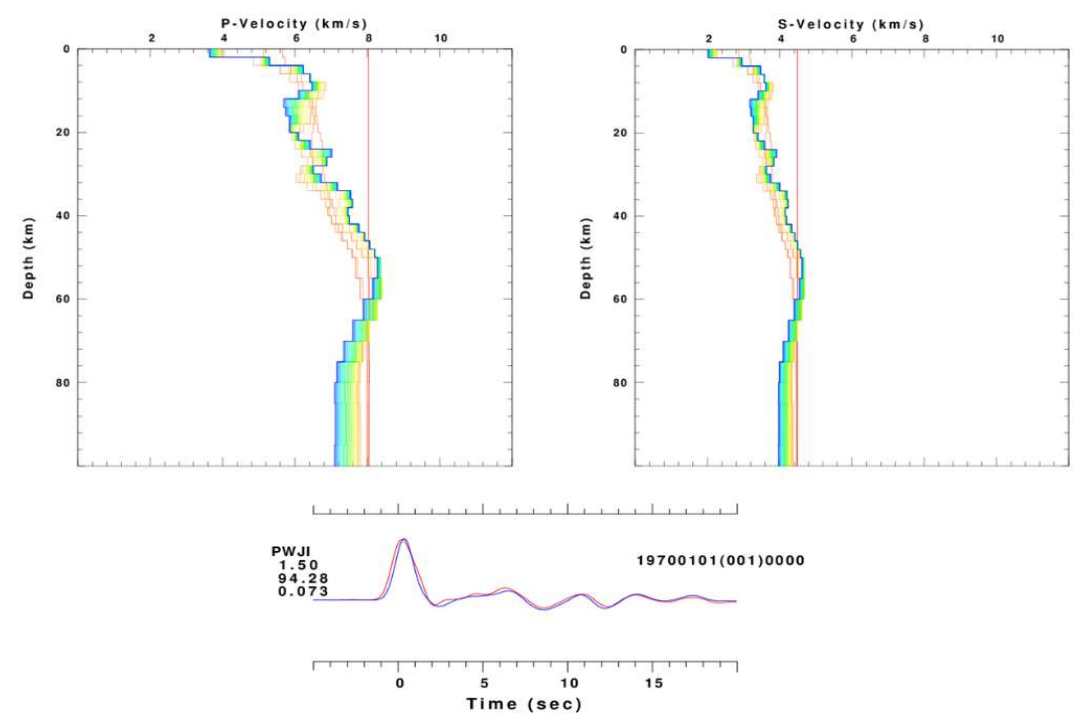

Gambar 18. Model kecepatan gelombang $P$ (panel kiri atas) dan gelombang $S$ (panel kanan atas) di bawah stasiun PWJI. Garis biru merupakan hasil akhir model kecepatan, garis merah merupakan model kecepatan awal, dan garis warna-warni merupakan proses iterasi model kecepatan. Panel bagian bawah merupakan fitting fungsi penerima observasi dan model digambarkan oleh garis biru dan merah.

Sementara itu, pada grafik kecepatan gelombang $S$ stasiun PWJI menunjukkan bahwa kecepatan gelombang $S$ memiliki nilai minimum sekitar $2,0 \mathrm{~km} / \mathrm{s}$ yang meningkat secara perlahan dari permukan hingga kedalaman $\sim 10 \mathrm{~km}$ menjadi $\sim 3,6 \mathrm{~km} / \mathrm{s}$. Kemudian kecepatan gelombang $S$ mengalami perubahan secara fluktuatif hingga kedalaman $\sim 34 \mathrm{~km}$. Pada kedalaman ini, seperti halnya gelombanp $P$, gelombang $S$ mengalami kenaikan $\sim 3,6 \mathrm{~km} / \mathrm{s}$ hingga $4 \mathrm{~km} / \mathrm{s}$ pada lapisan Moho. Selanjutnya kecepatan gelombang meingkat secara perlahan hingga sekitar 4,6 km/s. Setelah itu, kecepatan gelombang mengalami penurunan hingga kecepatan $\sim 3,9 \mathrm{~km} / \mathrm{s}$ dan selanjutnya stabil.

Hasil inversi fungsi penerima berupa model kecepatan gelombang $P$ dan $S$ pada stasiun GEJI memperoleh nilai kecocokan sebesar 93,68\% antara sinyal hasil observasi dengan model (Gambar 19). Pada profil kecepatan gelombang $P$ di bawah stasiun GEJI memiliki 
nilai sekitar $3,8 \mathrm{~km} / \mathrm{s}$ di permukaan hingga kedalaman $\sim 14 \mathrm{~km}$ mengalami peningkatan dari kecepatan sekitar 3,8 km/s menjadi $\sim 9,5$ $\mathrm{km} / \mathrm{s}$. Selanjutnya kecepatan gelombang $P$ mengalami perubahan fluktuatif hingga kedalaman $\sim 48 \mathrm{~km}$. Kecepatan gelombang $P$ kemudian naik secara perlahan hinga 10,6 $\mathrm{km} / \mathrm{s}$, namun selanjutnya turun kembali dan stabil pada kecepatan $\sim 8,6 \mathrm{~km} / \mathrm{s}$.



Model kecepatan gelombang $S$ pada stasiun GEJI memiliki nilai minimum sekitar $2,1 \mathrm{~km} / \mathrm{s}$ dari permukaan yang kemudian naik secara perlahan hingga $\sim 5,3 \mathrm{~km} / \mathrm{s}$ pada kedalaman $\sim 14 \mathrm{~km}$. Kecepatan gelombang $S$ selanjutnya mengalami perubahan secara fluktuatif dari kedalaman sekitar 14-48 km. Kemudian terjadi peningkatan kecepatan gelombang menjadi $\sim 5,9 \mathrm{~km} / \mathrm{s}$ pada kedalaman sekitar $65 \mathrm{~km}$.

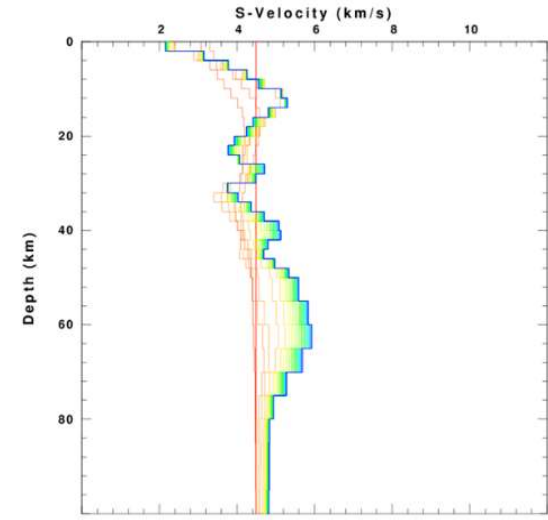

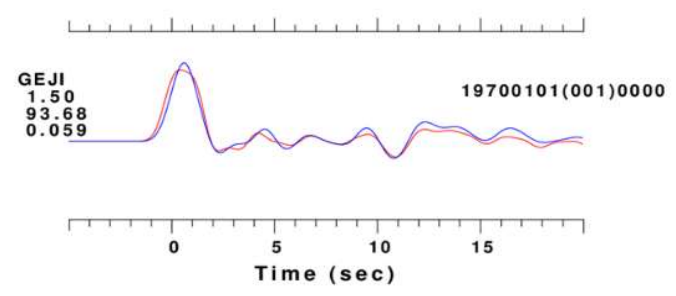

Gambar 19. Model kecepatan gelombang $P$ (kiri) dan gelombang $S$ (kanan) di bawah stasiun GEJI. Garis biru merupakan hasil akhir model kecepatan, garis merah merupakan model kecepatan awal, dan garis warna-warni merupakan proses iterasi model kecepatan. Panel bagian bawah merupakan fitting fungsi penerima observasi dan model digambarkan oleh garis biru dan merah.

Untuk menganalisis diskontinuitas Moho di bawah stasiun dilakukan migrasi fungsi penerima ke kedalaman sebagaimana yang ditunjukkan oleh Gambar 20. Pada plot fungsi penerima stasiun PWJI yang ditunjukkan oleh Gambar 20(a), kedalaman Moho diestimasi pada kedalaman sekitar $34-37 \mathrm{~km}$ yang ditandai dengan garis hitam putus-putus. Sementara itu, pada stasiun GEJI yang ditampilkan oleh Gambar 19(b) kedalaman
Moho teramati pada $37-40 \mathrm{~km}$ yang ditandai dengan garis hitam putus-putus. Pada hasil migrasi fungsi penerima ke kedalaman stasiun PWJI dan GEJI juga terlihat adanya delay fase gelombang $P$ langsung pada kedalaman $\sim 2 \mathrm{~km}$ yang diiterpretasikan berasal dari lapisan sedimen di bawah zona ini. Ketebalan sedimen ini juga sesuai dengan penelitian Anggono dkk. (2020) yang melakukan penelitian di Zona Pegunungan Selatan Jawa Barat dengan 
ketebalan 1-2 km. Selain itu, juga terlihat bahwa adanya fase polaritas negatif (low velocity zone (LVZ)) pada kedalaman sekitar 20 hingga $30 \mathrm{~km}$ yang kemungkinan berasal dari fluida magma atau lelehan parsial dibawah stasiun. Keberadaan fase LVZ ini merupakan hal yang menarik yang membutuhkan studi lebih lanjut.
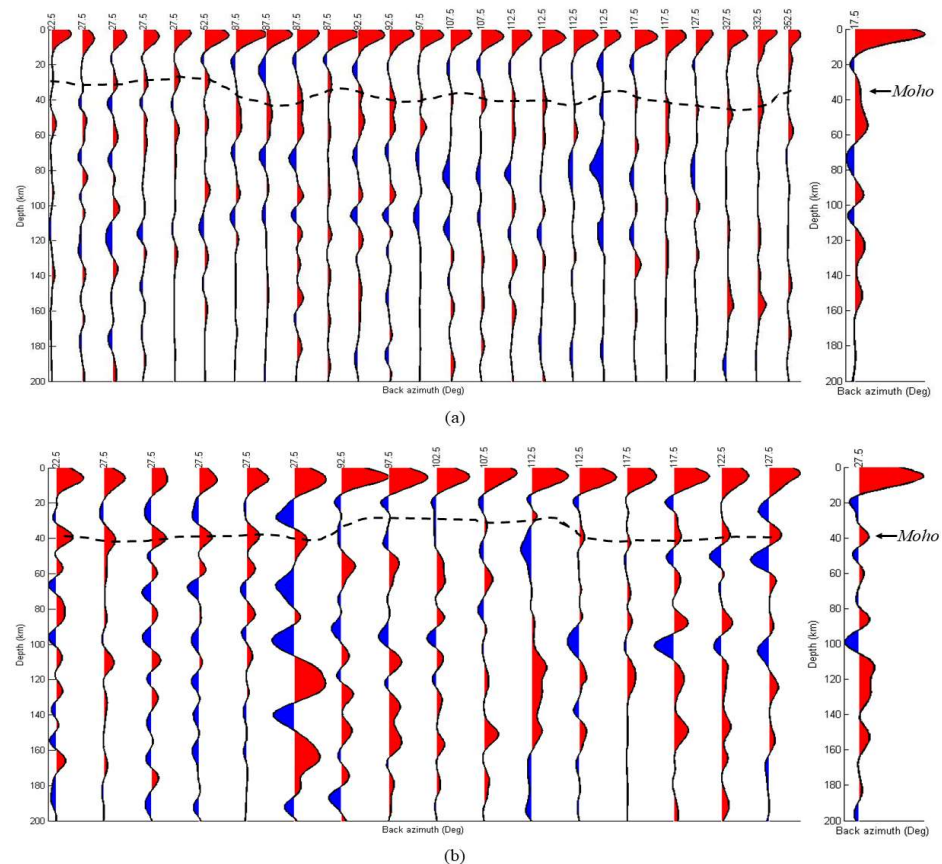

Gambar 20. Hasil migrasi fungsi penerima ke kedalaman di stasiun PWJI (a) dan stasiun GEJI (b) yang berada di Zona Pegunungan Selatan. Kedalaman lapisan Moho ditandai dengan garis hitam putusputus.

\subsection{Rekapitulasi Hasil Fungsi Penerima}

Secara ringkas hasil kedalaman Moho dari analisis fungsi penerima pada 6 stasiun seismik 3 komponen broadband BMKG di Jawa Timur disajikan pada Tabel 2. Ketebalan kerak pada Zona Rembang, yaitu pada stasiun TBJI adalah 25-28 km. Hasil ini sesuai dengan penelitian fungsi penerima dengan metode inversi Neighborhood Algorithm (NA) oleh Ariyanto (2018), dimana lapisan diskontinuitas Moho teridentifikasi pada kedalaman 27,8 km. Selanjutnya, kedalaman Moho pada stasiun GRJI adalah $23-27 \mathrm{~km}$, sesuai dengan peneltian Bahri dkk. (2021). Penelitian ini menggunakan metode fungsi penerima dengan lebar filter Gaussian 2,5 yang menyimpulkan bahwa kedalaman Moho di bawah stasiun GRJI adalah
$22 \mathrm{~km}$. Pada Zona Kendeng yang diwakili oleh stasiun LUJI dan ABJI, kedalaman lapisan Moho memiliki nilai yang sama yaitu diperkirakan pada kedalaman 18-20 km. Kedalaman Moho ini berasosiasi dengan salah satu stasiun pada penelitian yang dilakukan oleh Ariyanto (2018) di Jawa Tengah yang berlokasi pada Zona Kendeng. Pada penelitian tersebut, lapisan Moho di Zona Kendeng diidentifikasi pada kedalaman 19,5 km. Dari penelitian sebelumnya oleh Wölbern dan Rümpker (2016), menyatakan bahwa lapisan Moho pada Zona Kendeng mengalami pendangkalan 3-4 km karena adanya efek cekungan Kendeng dengan sedimen yang sangat tebal. Sementara itu, ketebalan kerak pada Zona Pegunungan Selatan yang diwakili 
oleh stasiun PWJI dan GEJI menunjukkan hasil secara berturut-turut yaitu 34-37 km dan $37-40 \mathrm{~km}$. Hasil penelitian ketebalan kerak zona ini berkesuaian dengan penelitian Anggono dkk. (2020) serta Wölbern dan Rümpker (2016), yang menunjukkan bahwa kedalaman Moho di bawah stasiun Zona pegunungan selatan sekitar $37 \mathrm{~km}$.

Dari analisis ketebalan kerak bumi di 3 zona geologi di Jawa Timur diatas, dapat diketahui bahwa Zona Kendeng mempunyai ketebalan kerak relatif tipis, Zona Rembang mempunyai ketebalan sedang, dan Zona Pegunungan Selatan dengan ketebalan kerak paling tebal. Adanya penebalan dan penipisan kerak pada zona ini dapat terjadi karena adanya efek isostasi, yaitu adanya kompensasi massa dimana kerak yang lebih berat atau lebih tebal seperti pada busur pegunungan, kerak bumi akan terbenam lebih dalam ke ke lapisan mantel, dan juga sebaliknya. Hasil serupa juga didapatkan oleh Xu dkk. (2013) yang melakukan penelitian kerak bumi di Dataran Tinggi Tibet, dimana ketebalan kerak dari 50 $\mathrm{km}$ menebal hingga $75 \mathrm{~km}$ di bawah blok Pegunungan Himalaya. Ryan dkk. (2016) dengan metode yang sama juga mendapatkan adanya penebalan kerak di Pegunungan Andean Tengah hingga 55-60 km.

Tabel 2. Ringkasan hasil struktur kerak bumi dari analisis fungsi penerima pada 6 stasiun seismik BMKG di Jawa Timur.

\begin{tabular}{|c|c|c|c|c|c|}
\hline \multirow[b]{2}{*}{ Zona } & \multirow[b]{2}{*}{ Stasiun } & \multirow{2}{*}{$\begin{array}{c}\text { Jumlah } \\
\text { sinyal }\end{array}$} & \multicolumn{3}{|c|}{ Struktur Kerak } \\
\hline & & & Ketebalan kerak (km) & $\begin{array}{c}\mathrm{vp} \\
(\mathrm{km} / \mathrm{s})\end{array}$ & $\begin{array}{c}\mathrm{vs} \\
(\mathrm{km} / \mathrm{s})\end{array}$ \\
\hline \multirow{2}{*}{ Rembang } & TBJI & 38 & $25-28$ & 8,12 & 4,53 \\
\hline & GRJI & 44 & $23-27$ & 7,48 & 4,17 \\
\hline \multirow{2}{*}{ Kendeng } & LUJI & 19 & $18-20$ & 6,71 & 3,75 \\
\hline & ABJI & 42 & $18-20$ & 7,07 & 3,94 \\
\hline \multirow[t]{2}{*}{ Pegunungan Selatan } & PWJI & 38 & $34-37$ & 7,44 & 4,15 \\
\hline & GEJI & 25 & $37-40$ & 8,78 & 4,98 \\
\hline
\end{tabular}

Sementara itu, dari profil kecepatan gelombang $P$ dan $S$ pada 6 stasiun di 3 zona geologi yang berbeda didapatkan hasil yang menarik, yaitu adanya kemiripan struktur pada stasiun di zona geologi yang sama. Pada Zona Pegunungan Selatan Jawa Timur, kecepatan gelombang seismik didominasi oleh $v_{p}$ dan $v_{s}$ yang relatif tinggi, pada Cekungan Kendeng didominasi oleh $v_{p}$ dan $v_{s}$ yang rendah, dan pada Zona Rembang yang berada di Utara Zona Kendeng didominasi dengan $v_{p}$ dan $v_{s}$ sedang. Rekapitulasi kecepatan gelombang $P$ dan $S$ di setiap Zona dapat dilihat pada Tabel 2. Hasil penelitian ini sesuai dengan penelitian sebelumnya oleh Martha dkk. (2017) yang mengklasifikasikan zona di Jawa Timur dari nilai $v_{\mathrm{s}}$-nya menjadi 3 , yaitu: Zona
Pegunungan Selatan dengan $v_{\mathrm{s}}$ tinggi, Zona Kendeng dengan $v_{s}$ sangat rendah dan Zona rembang dengan $v_{\mathrm{s}}$ sedang. Nilai kecepatan gelombang seismik ini sangat dipengaruhi oleh batuan dasar penyusunnya. Pada Zona Rembang batuan dasar penyusun daerah tersebut adalah endapan vulkanik dan aluvial modern serta batuan karbonat. Sedangkan pada Zona Kendeng merupakan daerah dengan cekungan sedimen tebal sehingga nilai kecepatannya sangat rendah. Sementara itu, Zona Pegunungan Selatan didominasi oleh kecepatan gelombang yang relatif tinggi karena batuan penyusun pada zona ini merupakan batuan vulkanik intrusif berumur OligoMiosen dan karbonat Miosen Tengah. 


\section{KESIMPULAN}

a. Ketebalan kerak bumi pada Zona Rembang bervariasi antara $25-28 \mathrm{~km}$ di bawah stasiun TBJI dan 23-27 km pada stasiun GRJI. Pada Zona Kendeng yang diwakili oleh stasiun LUJI dan ABJI, kedalaman lapisan Moho memiliki nilai yang sama yaitu diperkirakan pada kedalaman $18-20 \mathrm{~km}$. Sementara itu, pada Zona Pegunungan Selatan, ketebalan kerak relatif tebal yaitu pada kedalaman 34 $37 \mathrm{~km}$ di bawah stasiun PWJI dan 37-40 km pada stasiun GEJI. Adanya penebalan dan penipisan kerak dipengaruhi oleh adanya efek isostasi.

b. Model kecepatan gelombang $P$ dan gelombang $S$ pada Zona Rembang memiliki nilai yang relatif sedang, dimana berasosiasi dengan batuan penyusunnya merupakan endapan vulkanik dan aluvial modern. Pada Zona Kendeng, kecepatan gelombang $P$ dan gelombang $S$ memiliki nilai yang relatif rendah dibandingkan dengan zona lainnya karena merupakan Cekungan dengan sedimen tebal. Sedangkan pada Zona Pegunungan Selatan, model kecepatan gelombang $P$ dan $S$ memiliki nilai yang relatif tinggi, dimana berasosiasi dengan batuan penyusunannya adalah batuan vulkanik intrusif berumur Oligo-Miosen dan karbonat Miosen Tengah.

\section{UCAPAN TERIMA KASIH}

Penulis mengucapkan terima kasih kepada BMKG yang sudah memberikan data, Komite Kajian Gempa dan Tsunami yang telah mendukung penelitian ini, R.B. Herrmann dan K.C. Eagar yang menyediakan software, serta pihak-pihak terkait yang telah memberi dukungan terhadap penelitian ini.

\section{DAFTAR PUSTAKA}

Anggono, T., Syuhada, S., Febriani, F., Handayani, L., Mukti, M. M., \& Amran, A. (2020). Crustal Shear-Wave Velocity Structure in Western Java, Indonesia from Analysis of Teleseismic Receiver
Functions. Journal of Earth System Science, 129(1). https://doi.org/10.1007/s12040-0191288-1

Ariyanto, P. (2018). Struktur Kerak Bumi Di Jawa Bagian Tengah Berdasarkan Analisis Fungsi Penerima Teleseismik Menggunakan Inversi Algoritma Neighbourhood. Universitas Indonesia.

Ariyanto, P., Rosid, M. S., Syuhada, \& Januarti, Y. (2018). A Comparison of Tele-Seismic Receiver Function in The Different Geological Units in Central Java. EAGE-HAGI 1st Asia Pacific Meeting on Near Surface Geoscience and Engineering. https://doi.org/10.3997/22144609.20

Ariyanto, P., Rosid, M. S., Syuhada, \& Januarti, Y. (2021). Study of Crustal Structure Beneath Station Banjarnegara Indonesia (BJI) Based on Receiver Function Analysis. Journal of Physics: Conference Series.

Bahri, S., Suryanto, W., \& Ngadmanto, D. (2021). Sediment and Crustal Structure Beneath East Kalimantan and East Java, Indonesia from Receiver Function. Journal of Physics: Conference Series, 1825(1), 012014.

BMKG. (2019). Katalog Gempa Bumi Signifikan dan Merusak 1821-2018.

BMKG. (2021). Katalog Gempa Bumi. BMKG Data Archives. https://geof.bmkg.go.id/webdc3/

Chen, Y., \& Niu, F. (2016). Joint Inversion of Receiver Functions and Surface Waves with Enhanced Preconditioning on Densely Distributed CNDSN Stations: Crustal and Upper Mantle Structure Beneath China. Journal of Geophysical Research: Solid Earth, 121(2), 743-766. https://doi.org/10.1002/2015jb012450

Herrmann, R. B. (2013). Computer Programs in Seismology: An Evolving Tool for Instruction and Research. Seismological Research Letters, 84(6), 1081-1088. https://doi.org/10.1785/0220110096

ISC. (2021). ISC Bulletin: Arrivals Search. http://www.isc.ac.uk/iscbulletin/search/arrivals/

Jarchow, C. M., \& Thompson, G. A. (1989). The Nature of The Mohorovicic Discontinuity. Annual Review of Earth and Planetary Sciences. Vol. 17, No. 1, 475-506.

Julià, J., Ammon, C. J., Herrmann, R. B., \& Correig, A. M. (2000). Joint Inversion of Receiver 
Function and Surface Wave Dispersion Observations. Geophysical Journal International, 143(1), 99-112. https://doi.org/10.1046/j.1365246x.2000.00217.x.

Katili, J. A. (1975). Volcanism and Plate Tectonics in The Indonesian Island Arcs. Tectonophysics, 26(3-4), 165-188.

Kennett, B. L. N., Engdahl, E. R., \& Buland., R. (1995). Constraints on Seismic Velocities in The Earth from Traveltimes. Journal International Geophysics, 122, 108-124.

Lay, T., \& Wallace, T. C. (1995). Modern Global Seismology (International Geophysics Series, Volume 58). Academic Press.

Ligorría, J. P. (2000). An Investigation of The Mantle-Crust Transition Beneath North America and Poisson's Ratio of The North American Crust. Saint Louis University.

Ligorría, J. P., \& Ammon, C. J. (1999). Iterative Deconvolution and Receiver-Function Estimation. Bulletin of The Seismological Society of America, Vol. 89, No. 5, 1395-1400.

Martha, A. A., Cummins, P., Saygin, E., Widiyantoro, S., \& Masturyono. (2017). Imaging of Upper Crustal Structure Beneath East Java-Bali, Indonesia with Ambient Noise Tomography. Geoscience Letters, 4(1). https://doi.org/10.1186/s40562-017-0080-9

Menke, W. (1989). Geophysical Data Analysis: Discrete Inverse Theory. Academic Press.

PUSGEN, T. P. S. G. N. (2017). Peta Sumber dan Bahaya Gempa Indonesia Tahun 2017.

PVMBG. (2021). MAGMA Indonesia. https://magma.vsi.esdm.go.id/\#

Ryan, J. S., Beck, G., Zandt, L., Wagner, E., Minaya, H., \& Tavera. (2016). Central Andean Crustal
Structure from Receiver Function Analysis. Tectonophysics, 682, 120-133.

Smyth, H. (2005). East Java: Cenozoic Basins, Volcanoes and Ancient Basement. Indonesian Petroleum Association 30th Annual Convention Proceedings, Advance Access Published 2005.

Stein, S., \& Wysession, M. (2005). An Introduction to Seismology, Earthquakes, and Earth Structure. Blackwell publishing: Victoria 3053.

Syuhada, D.H., N., I. A., C., T.P., N., A., T., \& Y., T. (2016). Crustal Structure Along Sunda-Banda Arc Transition Zone from Teleseismic Receiver Functions. Acta Geophysica, 64(4), 2020-2050.

Van Bemmelen, R. W. (1949). The Geology of Indonesia (2nd ed.). General Geology of Indonesia and Adjacent Archipelagoes.

Wölbern, I., \& Rümpker, G. (2016). Crustal Thickness Beneath Central and East Java (Indonesia) Inferred from P Receiver Functions. Journal of Asian Earth Sciences.

Xu, M., Huang, H., Huang, Z., Z., H., \& Wang, L. (2016). SplitRFLab: A MATLAB GUI Toolbox for Receiver Function Analysis Based on SplitLab[J]. Earthquake Science, 29(1), 17-26.

Xu, Z. J., Song, X., \& Zhu, L. (2013). Crustal and Uppermost Mantle S Velocity Structure Under Hi-CLIMB Seismic Array in Central Tibetan Plateau from Joint Inversion of Surface Wave Dispersion and Receiver Function Data. Tectonophysics, 584, 209-220.

Yu, Y., Song, J., Liu, K. H., \& Gao, S. S. (2015). Determining Crustal Structure Beneath Seismic Stations Overlying a Low-Velocity Sedimentary Layer Using Receiver Functions. Journal of Geophysical Research: Solid Earth, 120(5), 32083218. 